\title{
Soil Physic-chemical Properties in Termite Mounds and Adjacent Control Soil in Miyo and Yabello Districts of Borana Zone, Southern Ethiopia
}

\author{
Abiyot Lelisa Deke ${ }^{1,}$, , Wondimu Tolcha Adugna ${ }^{1}$, Amsalu Tilahun Fite ${ }^{2}$ \\ ${ }^{1}$ Yabello Pastoral and Dry Land Agriculture Research Center, Yabello, Ethiopia \\ ${ }^{2}$ Department of Natural Resource Management, Jimma University, Jimma, Ethiopia \\ Email address: \\ labiyot@yahoo.com (A. L. Deke), kuleshawa@gmail.com (W. T. Adugna), amsetilahun@gmail.com (A. T. Fite) \\ ${ }^{*}$ Corresponding author

\section{To cite this article:} \\ Abiyot Lelisa Deke, Wondimu Tolcha Adugna, Amsalu Tilahun Fite. Soil Physic-chemical Properties in Termite Mounds and Adjacent \\ Control Soil in Miyo and Yabello Districts of Borana Zone, Southern Ethiopia. American Journal of Agriculture and Forestry. \\ Vol. 4, No. 4, 2016, pp. 69-74. doi: 10.11648/j.ajaf.20160404.11
}

Received: May 28, 2016; Accepted: June 12, 2016; Published: July 4, 2016

\begin{abstract}
This study was conducted in two districts of Borana (Yabello and Miyo). The objective of the study was to examine the soil texture and macronutrient distribution in termite mounds in relation to adjacent soil. Standard procedures were used to analyse the soil physic-chemical properties. One way ANOVA was used to compare results among control soil, external termite mound and internal termite mound materials. The study revealed that termites had produced a soil different in soil texture and some nutrient content than the surrounding soils. Internal termite mound at both study sites were enriched with clay in relation to external and control soil. SOM and CEC contents of control soils were higher at Boku Luboma. SOM content of external termite mound at Did Yabello was lower in relation to internal termite mound and control soil. The termite mound at Did Yabello had higher CEC content in relation to the surrounding soil. Ex. Ca content of termite mound did not show significant difference in relation to control soil. Termite activities enriched mound soil with Exchangeable potassium content. In order to design proper termite management techniques, termite species in Borana should be identified. There is no trend of termite mound use as soil amendment in Borana. In future, amount of termite materials to be incorporated to soil to increase crop yield and socio economic factors that affect use of termite materials as soil amendment should be studied.
\end{abstract}

Keywords: External Termite Mound, Internal Termite Mound, Soil Physic-chemical Properties, Borana

\section{Introduction}

Increasingly, it is being recognized that termites are an important component of agro-ecosystems, particularly in developing countries where they are an alternative to high priced inputs. Mound-building termites are recognized as "ecosystem engineers" because they promote soil transformation by disturbance processes [1]. They collect particles from different soil depths and deposit them in mounds, so that contents of organic carbon, clay and nutrients, $\mathrm{pH}$ and microbial population are higher in termite mounds than in the adjacent soils unmodified by termites [2]. The accumulated material is later redistributed by erosion causing changes in soil micro-structure and fertility [2, 3, 4].
Given the major problems in the Sahel of soil crusting and nutrient depletion, termites can play a vital role if proper management techniques are practiced. Termites contribute to the rehabilitation of crusted soils, by opening up voids on the sealed surface leading to improved infiltration capacity, and consequently improved water availability.

Although termites are the most important soil fauna in the semi-arid tropics [5], they are often regarded as pest because they attack roots, and above ground plants, and stored food supplies [6]. As a result, termite research in agro ecosystems, has historically concentrated on the pest management aspects. However, of more than 2500 species [7], relatively few are agricultural pests. Furthermore, pest activity is only a part of the termites' potential role in agro ecosystems [8].

In Borana lowland, both mound building and moundless 
termites are abundant and widely distributed Barnett et al. [8]. Termite mounds are conspicuous features of Borana landscape. Their materials can be differentiated from the adjacent soils by their different physic-chemical properties that impact some soil processes. Usually high concentration of organic matter and mineral nutrients are found in termite mound than in the surrounding soils. Consequently, subsistence farmers in Africa commonly spread termite mound materials in their fields to improve soil conditions and increase plant nutrient availability $[10,11]$. They also promote nutrient availability, nutrient cycling and soil physical properties [8].

However, according to Gauchan et al. [12], research on termite in Ethiopia has been concentrated on only the pest management aspects. Thus, generally in Ethiopia and particularly in the study area; the impact of mound-building termites on soil ecology in general and soil physic-chemical properties in particular were not yet studied. The aim of the study was to examine the soil texture and macronutrient distribution in termite mounds in relation to adjacent soil in Miyo and Yabello districts of Borana.

\section{Materials and Methods}

\subsection{Description of Study Area}

The study was conducted in Yabello (Did Yabello) and Miyo (Boku Luboma) districts of Borana zone. The rain fall is bi-modal. There are four seasons in the year namely; the Gana-long rainy season (March-May), the Bona-dry season (December-February), Hagaya-short rainy season (September-November) and the Adolesa-cool dry season (June-August) [13]. The study area comprises important cultural landscapes that have been utilized for centuries. The study area is also confronted with the problem of bush expansion in the native savannah grass lands.

\subsection{Site Selection and Sample Collection}

The study sites (Yabello-Did Yabello and Miyo-Boku Luboma) were selected because of widespread termite mounds in these areas. In each location, replications of three termite mounds were selected on a uniform slope. Internal mound and external mounds were sampled separately after destruction of termite mound. The external/wall of the termite mounds were sampled after scratching and removing the outer surface of mound materials. The internal termite mound (chamber) with thin structure was sampled separately.

In order to evaluate some soil physic-chemical properties of termite mounds in relation to the surrounding soils, a total of six adjacent (control) soils, three in each location were sampled for this study. The control soil was sampled at soil depth of $0-25 \mathrm{~cm}$ and $0-23 \mathrm{~cm}$ for Did Yabello and Boku Luboma sites respectively in a relatively unaffected area at reasonable distance from mounds. Control soils were considered to be the reference soils without significant termite activity. Termite mound and its corresponding control soils were located on comparative slope gradients in order to remove further differences that can be introduced due to topographic effects. Thus, any difference in soil physicchemical properties between termite mound materials and adjacent soil was attributed to the effects of mound-building termites.

\subsection{Physic-chemical Analysis of Control Soils and Termite Mound Materials}

The soil samples were air dried, ground, mixed well and passed through a $2 \mathrm{~mm}$ sieve for analysis. Particle size analyses were performed using the Bouyocous hydrometer method [14]. The USDA particle size classes, namely: sand $(2.0-0.05 \mathrm{~mm})$, silt $(0.05-0.002 \mathrm{~mm})$ and clay $(<0.002 \mathrm{~mm})$ were followed for assigning textural classes.

Soil $\mathrm{pH}\left(\mathrm{H}_{2} \mathrm{O}\right)$ was measured using $\mathrm{pH}$-meter in a 1:2.5 soil water ratio [14]. Determination of organic carbon content was carried out following the Walkley and Black wet digestion procedure [15] and the percent soil organic matter (SOM) was calculated by multiplying the percent organic carbon by a factor of 1.724 [16] and total nitrogen was determined by the Kjeldhal method [17]. Available phosphorus analysis was undertaken according to the method described by Olsen et al. [18]. Exchangeable bases (Ca, $\mathrm{Mg}$ and $\mathrm{K}$ ) were analyzed after extraction using $1 \mathrm{M}$ ammonium acetate method at $\mathrm{pH}$ 7.0. Exchangeable $\mathrm{Ca}$ and $\mathrm{Mg}$ in the extracts were read using atomic absorption spectrophotometer whereas Exchangeable $\mathrm{K}$ was read by flame photometer. After displacement of the exchangeable base forming cations using $1 \mathrm{M}$ ammonium acetate, the samples were washed using ethanol and the ammonium on the saturated exchange sites were subsequently replaced by the addition of $\mathrm{Na}$ from $\mathrm{NaCl}$ solution. Cation exchange capacity (CEC) was thereafter estimated titrimetrically by distillation of ammonium that was displaced by sodium [19].

\subsection{Data Analysis}

The soil physic-chemical data were analysed using SAS software [20]. One way ANOVA was used to compare soil physic-chemical properties among control soil, internal termite mound and external termite mound. Differences were considered significant only when $\mathrm{p}$ values were lower than 0.05 .

\section{Results and Discussion}

\subsection{Particle Size Distribution}

The textural class of the control soil was sandy loam for Did Yabello site and loam for Boku Luboma (Miyo) site. Particle size distribution in termite mound, internal and external, in relation to the control soil was affected by termites. Clay particles were significantly higher in the internal mound at both study sites $(34.6 \% \pm 3.8 \%$ clay particles at Yabello -Did Yabello and $49.2 \% \pm 1.4 \%$ at MiyoBoku Luboma). At Miyo site the silt content was significantly lower for internal mound where as silt content of Yabello site did not show difference at $p=0.05$. The sand 
content of internal termite mound was significantly lower for both sites $(\mathrm{p}<0.05$ at both study sites) (Table 1$)$.

Table 1. Soil particle size distribution of termite mound ${ }^{*}$.

\begin{tabular}{|c|c|c|c|}
\hline \multirow{2}{*}{ Parameters } & \multirow{2}{*}{ Part of Termite mound } & \multicolumn{2}{|l|}{ District } \\
\hline & & Yabello & Miyo \\
\hline \multirow{3}{*}{ Clay (\%) } & Internal mound & $34.6 \pm 3.82^{\mathrm{a}}$ & $49.2 \pm 1.4^{\mathrm{a}}$ \\
\hline & External mound & $22.9 \pm 5.20^{\mathrm{b}}$ & $40.4 \pm 0.7^{\mathrm{b}}$ \\
\hline & Control soil & $13.3 \pm 1.9^{b}$ & $21.7 \pm 1.9^{c}$ \\
\hline LSD & & 10.645 & 3.4706 \\
\hline \multirow{3}{*}{ Silt (\%) } & Internal mound & $12.9 \pm 1.4^{\mathrm{a}}$ & $25.8 \pm 1.4^{\mathrm{a}}$ \\
\hline & External mound & $11.7 \pm 10.0^{\mathrm{a}}$ & $29.6 \pm 1.9^{b}$ \\
\hline & Control soil & $6.7 \pm 0.7^{\mathrm{a}}$ & $31.7 \pm 0.7^{\mathrm{b}}$ \\
\hline LSD & & 12.934 & 2.7539 \\
\hline \multirow{3}{*}{ Sand $(\%)$} & Internal mound & $52.5 \pm 4.33^{\mathrm{a}}$ & $25.0 \pm 00^{\mathrm{a}}$ \\
\hline & External mound & $65.4 \pm 5.1^{\mathrm{b}}$ & $30.0 \pm 2.5^{b}$ \\
\hline & Control soil & $80.0 \pm 2.5^{\mathrm{c}}$ & $46.7 \pm 1.4^{\mathrm{c}}$ \\
\hline LSD & & 3.7783 & 4.4304 \\
\hline
\end{tabular}

${ }^{*}$ Means followed by different letters within column and district differ significantly at 5\% significance level.

As evidenced from this study soil termite mound was relatively enriched with clay in relation to the surrounding soil (control soil). This difference could be attributed to the preferential selection by termites during establishment of mound [21]. Manuwa observed similar trend in the clay content of termite mound in relation to the surrounding soil [22]. In contradiction to this trend Ackerman et al. [23] found slightly lower clay and higher silt and sand in his study which implies that in the presence of high clay materials ( $76 \%$ clay) termites collect and transport more silt and sand proportions to their mound in relation to the control soil. The increase in clay content by termite activity can be crucial in improving soil physic-chemical properties in soil in general and sandy-sandy loam soil in particular. This study shows that clay materials play a key role in the construction of termite mound.

\subsection{Soil pH}

The $\mathrm{pH}$ of external mound and internal mound were not significantly different in relation to the surrounding soil for both districts (Table 2) $(\mathrm{p}>0.05)$. The result is in agreement with study conducted by Brossard et al. [24] i.e. termite activity did not affect the soil $\mathrm{pH}$.

\subsection{Soil Organic Matter, Total Nitrogen and Av. $P$}

The SOM content of external mound was significantly lower than internal and control soil at Yabello site but differed significantly for control soil (higher SOM) for Miyo site. The decrease in SOM in termite mounds in relation to the control soil at Boku Luboma could be attributed to termite SOM depletion potential with other soil microorganisms [25]. Some researchers argue that the low SOM content in termite mound could be due to low SOM soil from subsoil used for mound construction [26]. Higher SOM for control soil was obtained by Jouquet et al. in relation to the termite mound [27]. In contradiction to this study, higher SOM content in termite mound in relation to the surrounding soil was obtained by Ackerman et al. in which the feeding habit and materials used for construction of the termite mound contributed to the elevated SOM [23].

Internal termite mound at Yabello site had significantly higher total nitrogen content than external termite mound and control soil (Table 2). The high amount of total nitrogen in the termite mound might be due to the mineralization of soil organic matter by termites. Ackerman et al. obtained higher TN content in termite mound [23].

The Av. P content of internal and external termite mound were non-significant $(\mathrm{p}>0.05)$ for Did Yabello and Boku Luboma sites (Table 2). These results are consistent with the study conducted by Ackerman et al. [23]. Although the feeding habit of termite and materials used for construction of mound can have significant impact on phosphorus sorption affecting availability of phosphorus for plant uptake [28], this trend was not observed in this study.

Table 2. Soil chemical properties of termite mound ${ }^{*}$.

\begin{tabular}{llll}
\hline \multirow{2}{*}{ Parameters } & Part of Termite mound & District & Miyo (Boku Luboma) \\
\cline { 3 - 4 } & & Yabello (Did Yabello) & $8.22 \pm 0.05^{\mathrm{a}}$ \\
\hline \multirow{2}{*}{$\mathrm{pH}(1: 2.5$ ratio) } & Internal mound & $6.77 \pm 0.72^{\mathrm{a}}$ & $7.97 \pm 0.33^{\mathrm{a}}$ \\
& External mound & $6.81 \pm 0.46^{\mathrm{a}}$ & $8.13 \pm 0.02^{\mathrm{a}}$ \\
LSD & Control soil & $6.75 \pm 0.53^{\mathrm{a}}$ & 0.4349 \\
TN (\%) & & 0.5799 & $0.078 \pm 0.014^{\mathrm{a}}$ \\
& Internal mound & $0.056 \pm 0.004^{\mathrm{a}}$ & $0.081 \pm 0.025^{\mathrm{a}}$ \\
LSD & External mound & $0.034 \pm 0.007^{\mathrm{b}}$ & $0.096 \pm 0.059^{\mathrm{a}}$ \\
Av. P (ppm) & Control soil & $0.040 \pm 0.04^{\mathrm{b}}$ & 0.0995 \\
& & 0.0135 & $5.00 \pm 0.92^{\mathrm{a}}$ \\
LSD & Internal mound & $5.73 \pm 0.90^{\mathrm{a}}$ & $2.80 \pm 1.39^{\mathrm{a}}$ \\
OM (\%) & External mound & $5.73 \pm 0.70^{\mathrm{a}}$ & $2.93 \pm 0.42^{\mathrm{a}}$ \\
\hline
\end{tabular}




\begin{tabular}{llll}
\hline \multirow{2}{*}{ Parameters } & Part of Termite mound & District & Miyo (Boku Luboma) \\
\cline { 3 - 4 } & Control soil & $0.76 \pm 0.11^{\mathrm{a}}$ & $2.55 \pm 00^{\mathrm{b}}$ \\
\hline & & 0.2857 & 0.4762 \\
LSD & Internal mound & $1.50 \pm 0.50^{\mathrm{a}}$ & $2.44 \pm 0.32^{\mathrm{a}}$ \\
Ex. K (meq/100 g soil) & External mound & $0.89 \pm 0.31^{\mathrm{b}}$ & $1.60 \pm 0.49^{\mathrm{b}}$ \\
& Control soil & $0.53 \pm 0.14^{\mathrm{b}}$ & $1.09 \pm 0.29^{\mathrm{b}}$ \\
LSD & & 0.5715 & 0.7571 \\
CEC (meq/100 g soil) & Internal mound & $10.65 \pm 0.50^{\mathrm{a}}$ & $8.29 \pm 1.90^{\mathrm{a}}$ \\
& External mound & $8.91 \pm 0.30^{\mathrm{a}}$ & $6.86 \pm 0.99^{\mathrm{a}}$ \\
LSD & Control soil & $3.24 \pm 3.12^{\mathrm{b}}$ & $12.03 \pm 1.3^{\mathrm{b}}$ \\
Ex. Ca (meq/100 g soil) & & 4.2836 & 3.4307 \\
& Internal mound & $6.17 \pm 1.66^{\mathrm{a}}$ & $34.58 \pm 3.98^{\mathrm{a}}$ \\
LSD & External mound & $5.79 \pm 0.56^{\mathrm{a}}$ & $43.45 \pm 2.30^{\mathrm{a}}$ \\
Ex. Mg (meq/100 g soil) & Control soil & $7.50 \pm 1.74^{\mathrm{a}}$ & $39.83 \pm 6.9^{\mathrm{a}}$ \\
& & 2.606 & 12.752 \\
LSD & Internal mound & $1.28 \pm 0.17^{\mathrm{a}}$ & $7.95 \pm 0.97^{\mathrm{a}}$ \\
\hline
\end{tabular}

${ }^{*}$ Means followed by different letters within column and district differ significantly at $5 \%$ significance level.

\subsection{Exchangeable Cations and CEC}

The internal termite mound had significantly higher exchangeable $\mathrm{K}$ (Ex. K) in relation to external termite mound and control soil at both sites (Table 2). This result is consistent with study conducted by Jouquet et al. [29]. According to the ratings by Jones [30] the exchangeable potassium content of the study area is medium $(0.53 \pm 0.14 \mathrm{ppm})$ for control soil and very high $(1.50 \pm 0.50 \mathrm{ppm})$ for internal termite mound at Yabello. Ex. K at Boku Luboma is rated as very high.

The Exchangeable calcium (Ex. Ca) content of termite mounds were non significant in relation to the adjacent soil. Research conducted by Jouquet et al. [29] revealed nonsignificant level of Ex. Ca in termite mound in relation to adjacent soil which is consistent with this study. Brossard et al. [24] obtained higher Ex. Ca in their study which was assumed to be caused by transportation of mineral soil from deep sub soils. The Ex. Ca is rated as medium for Did Yabello and very high for Boku Luboma site according to Jones [30] ratings. Exchangeable magnesium (Ex. Mg) content of Did Yabello external termite mound was significantly higher than internal termite mound and control soil. Ex. Mg content of control soil was significantly lower at Miyo site $(\mathrm{p}<0.05$, Table 2$)$ when compared with internal and external mound which is in agreement with study conducted by Jouquet et al. [29]. The differences in trends of the exchangeable cations could be attributed to soil types.

Control soil at Yabello had significantly lower CEC content than internal and external termite mound but higher at Boku Luboma - Miyo site. The difference in CEC between control soil and termite mound could be due to change in clay type as termites work on soil which is explained by different researchers [27,31]. Termites either decrease or increase clay's chemically active surface area which affect the soil's CEC content. Higher CEC for control soil is also obtained by Jouquet et al. [32]. Termite mounds with high
CEC value can be used to improve low CEC soils which further support plant growth-act as nutrient storage media.

\section{Conclusion}

The study was conducted to examine the soil texture and macronutrient distribution in termite mounds in relation to adjacent soil. Termites produced a soil that had different soil texture and some nutrient content than the surrounding soil in the study area. Termite mounds (internal and external mound) were enriched with clay soil in both study sites in relation to the surrounding soil. The clay content in sandy and sandy loam soil can be improved by incorporating the termite mound materials in to soil which intern improve soil physic-chemical properties. Termite mound materials in both study sites were enriched with Ex. K and Ex. Mg. The other soil properties studied did not show similar trend in both sites (Miyo-Boku Luboma and Yabello-Did Yabello). Termite mound (internal mound) of Did Yabello site was enriched with TN but that of Boku Luboma was non-significant in relation to adjacent soil. The SOM content of external termite mound at Did Yabello decreased in relation to internal mound and control. Cation exchange capacity of soil was improved by termite activity at Did Yabello site but decreased at Boku Luboma site.

Termite species have effect on soil physic-chemical properties; therefore, species of termites in Borana need to be identified. This helps to design proper termite management techniques without ecological damages so that one can make use of ecological services provided by termites. There is no trend of use of termite mound as soil amendment in Borana. In future, amount of termite mound materials that should be incorporated to soil to increase crop yield and socio economic factors that influence the use of termite materials as soil amendment should be studied. 


\section{Acknowledgment}

The authors would like to acknowledge Oromia Agricultural Research Institute (IQQO) for the financial support of the research. We thank Holeta Agriculture Research Center for soil analyses.

\section{References}

[1] Dangerfield, J. M., Mccarthy, T. S. and Ellery, W. N. (1998). The mound-building termite Macrotermes michaelseni as an ecosystem engineer. Journal of Tropical Ecology 14: 507-520.

[2] Black, H. I. J. and Okwakol, M. J. N. (1997). Agricultural intensification, soil biodiversity and agroecosystem function in the tropics: the role of termites. Applied Soil Ecology 6: 3753.

[3] Shaefer, C. E. (2001). Brazilian latosols and their B horizon microstructure as long-term biotic constructs. Australian Journal of Soil Research 39: 909-926.

[4] Jouquet, P., Traoré, S., Choosai, Ch., Hartmann Ch., \& Bignell, D. (2011). Influence of termites on ecosystem functioning, Ecosystem services provided by termites. European Journal of Soil Biology 47: 215-222

[5] Lobry de Bruyn, L. A. and Conacher, A. J. (1990). The role of termites and ants in soil modification: a review. Australian Journal of Soil Research 28 (1): 55-93.

[6] Wood, T. G. (1996). The agricultural importance of termites in the tropics. Agricultural Zoology Reviews 7: 117-155.

[7] Pearce, M. J. and Waite, B. S. (1994). A list of termite genera (Isoptera) with comments on taxonomic changes and regional distribution. Sociobiology 23: 247-259.

[8] Anderson, J. M. (1994). Functional attributes of biodiversity in land use systems. pp. 267-290. In: D. J. Greenland and I. Szablocs, (Editors), Soil Resilience and Sustainable Land Use $\mathrm{CAB}$ International, Wallingford.

[9] Barnett, E. A, Cowie, R. H., Sands, W. A. and Wood, J. G. (1987). Identification of termites collected in Ethiopia. Report No. C 0696. Tropical research institute, London.

[10] Watson, J. P. (1977). The use of mounds of the termite macrotermes falciger (gerstäcker) as a soil amendment. Journal of Soil Science 28 (4): 664-672.

[11] Nyamapfene, K. W. (1986). The use of termite mounds in Zimbabwe peasant agriculture. Tropical Agriculture 63: 152192.

[12] Gauchan, D., Ayo-Odongo, J., Vaughan, K., Lemmaa, G. and Mulugeta, N. (1998). A participatory system analysis of the termite situation in West Wellega, Oromia region, Ethiopia. International Centre for development oriented Research in Agriculture (ICRA), Wageningen, the Netherlands.

[13] Coppock, D. L. (1994). The Borana Plateau of Southern Ethiopia: Synthesis of pastoral research, development and change, 1980-91. ILCA (International Livestock Center for Africa), Addis Ababa Ethiopia, pp 418.

[14] Sahlemedhin Sertsu and Taye Bekele. 2000. Procedures for Soil and Plant Analysis. National Soil Research Center, Ethiopian Agricultural Research Organization.
[15] Walkley, A. and Black, I. A. M. (1934). An example of the degitiareff method for determining soil organic matter and a proposed modification of the chromic acid titration method. Soil Science 34: 29-38.

[16] Brady, N. C. (1990). The nature and properties of soils $10^{\text {th }}$ edition. Prentice-Hall Limited, India, pp 621.

[17] Jackson, M. L. (1958). Soil chemical analysis. Prentice-Hall, Inc. Englewood Cliffs, N. J, pp 216.

[18] Olsen, S. R., Cole, C. V., Watanabe, F. S. and Dean, L. A. (1954). Estimation of available phosphorus in soils by the extraction with sodium bicarbonate; Circ. 939; U.S. Department of Agriculture.

[19] Chapman, H. D. (1965). Total exchangeable bases. pp. 902904. In C. A. Black (Editor). Methods of soil analysis, Part II, Soil Science Society America., Madison, Wis.

[20] SAS. (2002). SAS Institute Inc., Cary, NC, USA, Version 9.

[21] Harry, M., Jusseaume, N., Gambier, B. and Garnier-Sillam, E., 2001. Use of RAPD markers for the study of microbial community similarity from termite mounds and tropical soils. Soil Biology and Biochemistry 33: 417 - 427.

[22] Manuwa, S. I. (2009). Physico-chemical and dynamic properties of termite mound soil relevant in sustainable food production. African Crop Science Society 9: 356 - 369.

[23] Ackerman, I. L., Teixeira, W. G., Riha, S. J., Lehmann, J. and Femandes, E. C. M. (2007). The impact of mound-building termites on surface soil properties in a secondary forest of Central Amazonia. Applied Soil Ecology. 37: 267-276.

[24] Brossard, M., Lopez-Hernandez, D., Lepage, M. and Claude Leprun, J. (2007). Nutrient storage in soils and nests of mound-building Trinervitermes termites in Central Burkina Faso: consequences for soil fertility. Biology and Fertility of Soils 43: 437-447.

[25] Dahlsjo, C. A. L., Parr, C. L., Malhi, Y., Meir, Chevarria, O. V. C. and Eggleton, P. (2014). Termites promote soil carbon and nitrogen depletion: Results from an in situ macrofauna exclusion experiment, Peru. Soil Biology \& Biochemistry 77: 109-111.

[26] Contour-Ansel, D., Garnier-Sillam, E., Lachaux, M. and Croci, V. (2000). High performance liquid chromatography studies on the polysaccharides in the walls of the mounds of two species of termite in Senegal, Cubitermes oculatus and Macrotermes subhyalinus: their origin and contribution to structural stability. Biology and Fertility of Soils. 31: 508-516.

[27] Jouquet, P., Guilleux, N., Shanbhag, R. R. and Subramanian, S. (2015). Influence of soil type on the properties of termite mound nests in Southern India. Applied Soil Ecology 96: 282-287.

[28] Hernandez, D. L., Brossard, M., Fardeau, J. C. and Lepage, M. (2006). Effect of different termite feeding groups on $P$ sorption and $\mathrm{P}$ availability in African and South American savannas. Biology and Fertility of Soils. 42: 207-214.

[29] Jouquet, P., Tessier, D., Lepage, M. (2004). The soil structural stability of termite nests: role of clays in Macrotermes bellicosus (Isoptera, Macrotermitinae) mound soils. European Journal of Soil Biology 40: 23-29.

[30] Jones, B. J. (2003). Agronomic handbook: management of crops, soils, and their fertility. CRC Press LLC, pp 450. 
[31] Mujinya, B. B., Mees, F., Erens, H., Dumon, M., Baert, G. Boeckx, P., Ngongo, Van Ranst, E. (2013). Clay composition and properties in termite mounds of the Lubumbashi area, D. R. Congo. Geoderma 192: 304-315.
[32] Jouquet, P., Guilleux, N., Caner, L., Chintakunta, S., Ameline, M. and Shanbhag, R. R. (2016). Influence of soil pedological properties on termite mound stability. Geoderma 262: 45-51. 